\title{
Store sten på Friluftskortet - og sagn fra en svunden tid
}

Af geolog Lise Holm og Henrik J. Granat, Skov- og Naturstyrelsen

$\mathrm{Nu}$ er det muligt at finde frem til nogle af Danmarks største sten via internettet på Skov- og Naturstyrelsens Friluftskort. Her kan du foreløbig finde de store sten, der ligger på offentlige arealer, men det er meningen, at store sten på private områder med offentlig adgang med tiden skal medtages.

Store sten har altid fascineret mennesker, og de fleste tager også godt vare på dem. Ofte har de store sten været omgivet af mystik, og har været forbundet med overtro fx sådan, at den, der ødelagde dem, ville lide en sørgelig skæbne. Dette gav stenene en vis beskyttelse. Til trods for dette er flere af dem alligevel $i$ tidens løb blevet sprængt $i$ stykker for at blive anvendt til mere "nyttige" formål. Det skete især i slutningen af 1800-tallet, i oplysningstiden. Store sten i sig selv er nemlig som sådan ikke omfattet af nogen form for beskyttelse, men hvis der er helleristninger, fx skåltegn indhugget, eller hvis der er tilknyttet et sagn, falder de ind under Naturbeskyttelseslovens definition af fortidsminder og er dermed beskyttet mod flytning $o g$ andre ændringer.

\section{Oversigt på ca. 100 store sten}

Skov- og Naturstyrelsen har en oversigt over ca. 100 store sten og foretog for nogle år siden en egentlig registrering af de sten, der har tilknyttede sagn. Det er nogle af dem, der nu er medtaget på Friluftskortet. Her kan man også læse om sagnene.

Styrelsen har desværre ikke en geologisk beskrivelse af ret mange af de store sten, og derfor opfordres alle, der ligger inde med sådanne beskrivelser (eller bare en kort karakteristik), til at sende dem til styrelsen. Især vil vi gerne høre om, hvis stenene har en karakter, hvor folk uden geologiske forudsætninger kan forstå en beskrivelse og en lille forklaring. Det kan for ekesmpel være særlige mineraler, pegmatitgange, folder og skurestriber.

Oplysninger om store sten er velkomne Internetsiden vil som nævnt løbende blive udvidet med flere af de registrerede sten. Vi er desuden også interesseret $\mathrm{i}$ oplysninger

Guldhøjstenen på nordsiden af Vejle Fjord. (Foto: Margareta Bekmose)

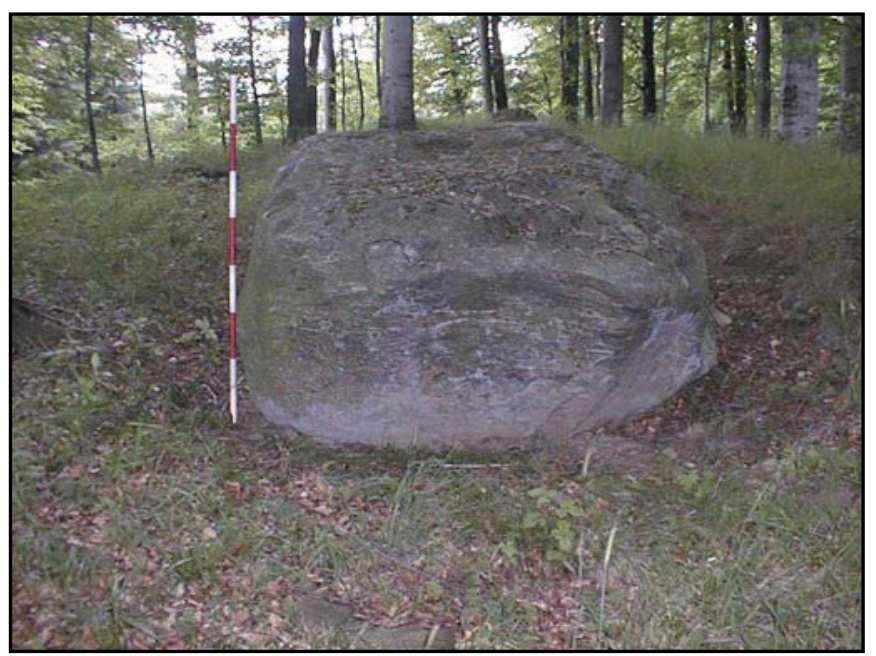

om andre store sten. En sten er stor, når den har en længde på mindst 3 meter.

På Friluftskortet findes i øvrigt meget anden god information om Skov- og Naturstyrelsens arealer. Her kan man læse om geologiske seværdigheder, fortidsminder og berømte træer, foruden praktiske oplysninger om bålpladser, fugletårne, lejrpladser, hundeskove, badesteder i søer og meget mere.

\section{Guldhøjstenen nord for Vejle Fjord}

Midt i den danske bøgeskov ligger en gammel gæst fra det svenske grundfjeld. En stor gnejsblok, der har lagt sig til rette på skråningen ned mod fjorden. Stenen er et vidnesbyrd om den tid, da Danmark var dækket af en iskappe, og om de store kræfter, som naturen besidder. Medmindre da nogen har lagt stenen her for at vogte en skat. Et gammelt sagn beretter nemlig sådan:

"En skat er begravet under stenen, men graver man efter den, dukker en høj, slank, grønklædt jæger frem med sin skytte og hunde, der myldrer frem fra alle sider. Det er den vilde jæger (Vojens jæger), Grev Ott. Han var en ugudelig krop. Under altergang tog han alterbrødet ud af munden og satte det på et "ligtræ" og skød til måls efter det. Derfor fik han aldrig ro efter døden men jager rundt i skoven."

Så nyd stenen uden at grave efter skatten, så skovens ro ikke bliver brudt.

Store sten kan findes her:

www.Friluftskortet.dk

Seværdigheder

Store sten

\section{Henvendelse kan ske til:}

Lise Holm og Henrik J. Granat Skov- og Naturstyrelsen Haraldsgade 53

København Ø Lho@sns.dkoghgr@sns.dk 